\title{
The Distribution of British Ability
}

\section{Author(s): Louisa E. Farquharson}

Source: The Celtic Review, Vol. 2, No. 6 (Oct., 1905), pp. 191-195

Stable URL: http://www.jstor.org/stable/30070144

Accessed: 27-06-2016 19:38 UTC

Your use of the JSTOR archive indicates your acceptance of the Terms \& Conditions of Use, available at

http://about.jstor.org/terms

JSTOR is a not-for-profit service that helps scholars, researchers, and students discover, use, and build upon a wide range of content in a trusted digital archive. We use information technology and tools to increase productivity and facilitate new forms of scholarship. For more information about JSTOR, please contact support@jstor.org. 


\section{The Distribation of British Ability}

Looking through some old numbers of the Monthly Review a few weeks ago, my attention was attracted to an article under the above heading. Readers may be interested by a few notes drawn from it, as tending to show how the increased obtrusiveness of the Celtic personality is continuously bringing out fresh evidence from the other side, and how new Anglo-Saxon warriors stand up to battle.

The writer of the article, Mr. Havelock Ellis, is a fair and liberal-minded man enough, but quite satisfied that England's superiority is as great where genius is concerned as it certainly is when it is a question of revenue and resources.

It is often loosely stated that to the Celtic element Great Britain as a whole owes much of her greatness, and I have wondered by what chain of evidence the Celtic enthusiast has arrived at this conclusion. It may not be unprofitable to learn how the other side works out the opposite case.

Mr. Havelock Ellis introduces his subject thus:-'In studying the characteristics of British genius, the first and most elementary question we have to settle is the distribution of British ability in the various parts of the United Kingdom. It is desirable to determine what proportion of British genius is produced respectively by England, Scotland, Ireland, and Wales. In so doing it is obvious that we shall not have classified our British men of genius strictly according to race, we shall not even have determined precisely the contribution of the so-called "Celtic" element to British genius, but we shall have taken an important and interesting first step. This is the question which, in the course of a somewhat elaborate study of the characteristics of British men of genius founded mainly on the Dictionary of National Biography, I have made an attempt to answer. I find that among 30,000 individuals included in the Dictionary 902 stand out as of pre-eminent ability.'

First let us ask. Is there not an anomaly in talking of the 'contribution' of the so-called 'Celtic' element to 'British' genius? Latter-day ethnology rather points to it that the Britains were Celts, and that the British survive in the Welsh of to-day. Secondly, why are we to accept Mr. Havelock Ellis's choice of 902 out of 30,000 , and the 2 makes us feel there was no particular reason why the enumerator stopped short just then. Why not pause at 900 ?

There is something very Teutonic in this soul-surrender to a Dictionarythis boiling down of the nation's heritage of genius to 902 .

After writing as above our essayist seems to have been struck with the idea that perhaps his selection might not be accepted unknown, and adds in a note, 'It would be tedious to explain here the principal of selection by which these 902 were obtained,' but refers us to a series of articles then appearing in the Popular Science Journal. He goes on to show the best way of determinating place of origin is not to note place of birth, but by con- 
sidering the districts to which the subject's four grandparents belong. In only a very small proportion of cases has he been able to determine the origins of all four grandparents, and has considered himself fortunate when able to tell where father and mother came from. Often, even in his desire to allot his geniuses to different counties, he has had to be content with merely finding out where the father came from. What does this prove as to the Celtic or Saxon origin of British genius? How does the plan of leaving the four grandparents outwork?

Supposing a Scottish servant, bearing the commonest name in ScotlandSmith-accompanied his master's daughter south on her marriage to an English squire, and on being settled in employment in Hampshire he sent for and married his Scottish sweetheart-Margaret Millar-would their son, James Smith, born in the New Forest, be an Englishman because Mr. Ellis failed to find out from their very ordinary names that John and Margaret, his parents, were from Scotland. Supposing James Smith to get a good education, and going into the county town became a clerk, worked his way up married an English girl, Sophia Barker, and fathered a genius of the name of William Smith, would that genius go to the English credit? William Smith, philosopher or scientist, would figure in the Dictionary as the son of James Smith, notary's clerk, of Winchester, and Sophia Barker of Alton, born at Winchester, but father James's sonship to John Smith from Scotland would not appear, and more than likely if we only knew John's father was Alasdair MacGow from beyont the Highland line. But this is a very supposititious case ; let us invent another.

Suppose Carroll were the name of some brilliant painter who, rising to fame, would be included in some future National Biography, with or without an R.A. to his name. His birthplace would be given as Cheltenham, his father an Indian officer born in Yorkshire, where his father was a clergyman. The clergyman himself would be found born in London, the son of a famous Dr. Carroll. A good, clear English pedigree, and Mr. Ellis, in all probability, would not feel bound to make further inquiries after the doctor - great-grandfather of the painter. But the painter might hold clear documentary proof that Dr. Carroll was the lineal representative of the Ely O'Carrolls of the King's county, none the less genuine because in his youth Dr. Carroll left Ireland to work under the English husband of his only sister, and through his advice dropped his distinguishing $O^{\prime}$, because in early nineteenth century days people mistrusted $O^{\prime}$ 's and Macs. I have written a pure romance, but will add a third.

The name of Price is above a London shop. Let us imagine a Price in Lancashire whose son became a famous mechanician and inventor-worldwide enough to be included in the fame-branding Dictionary. Price, the inventor, was born at Wigan-like his father before him-but the grandfather's birthplace is unknown to the Dictionary. Local information and the tell-tale $\mathrm{P}$ would send a broader minded student over the Welsh border, and, in some obscure mountain village, tradition would tell how young Hugh 
ap Rice went away in search of work with his Welsh wife and child, and that in Wigan the second son was born and became the father of the famous inventor, but the elder came back and lived and died among old Hugh's people, and so connected the younger with his real place of origin.

I cannot point to any celebrities called Smith, Carroll, and Price. To the average Englishman the possessors of those names would be written down English, but the Celts are not the children of two generations, so they absolutely refuse to be judged by the place of birth of two generations. They go out into far lands and remain Celts. Where would Mr. Ellis place the Glenaladale McDonalds, a hundred years on Prince Edward's Islands?

Let us study Mr. Ellis's exact figures. For some reason he does not analyse the original 902 eminent persons-they have shrunk to 779 . 'Speaking generally, it is found that 598 eminent British men and women are English, 117 Scotch, 41 Irish, and 23 Welsh-that is 78.8 per cent. English, 15.3 Scotch, 5.3 Irish, and 2.9 Welsh.' If we are allowed to take up a Pan-Celtic attitude we see 181 Celts as against 598 AngloSaxons, not quite a fourth, not so bad a proportion. Viewed as three separate units, the figures afford Mr. Ellis vast satisfaction. 'The preponderance of the English contingent is enormous, but if we take the present population as a basis, it is a reasonably fair distribution, a very slight excess over the first proportion being accountable by the greater advantages necessarily enjoyed by the English.' The italics are mine, and every Scotsman will rise up and refute the statement that the English enjoy greater advantages than themselves. Up to thirty years ago the percentage of illiterates was lower in Scotland than in England, her high schools and her universities are second to none. Lowland and Highland have loved learning for its own sake, and before secondary education or continuation classes were thought of, Scottish farm lads attended winter classes round some cottar's fire.

Coming to Wales, Mr. Ellis allows the proportion to be fair, though below what it should be, and for this he accounts according to his own ideas. 'We have to bear in mind the difficulty of a language not recognised as a medium of civilisation. As regards Scotland and Ireland the discrepancy is marked, the contribution of Scotland is much too large, that of Ireland much too small, in relation to the population. We probably have to recognise that intellectual aptitudes are especially marked among the Scotch, and also that the tendency has been fostered by circumstances since, as is well known, the lowland Scotch are almost identical in racial composition with the northern English, and there is no artificial barriers of language.'

Of what race were the northern English? How sure Mr. Ellis is that it is to English blood and Lowland strength old Scotland owes any little superiority he may allow her. Let him read in the January number of the Celtic Review Mr. Ferguson's statement of a clear case against a Teutonic absorption of the Celt in southern Scotland, maintaining there is no record of permanent successful invasion by the Angles of Northumbria, and only a peaceful settlement of Norman barons.

VOL, II. 
The Celtic Revival has evidently reached Mr. Ellis, but he cannot yet imagine a native language may be an education in itself, that a country may be busy producing native-speaking genius who find no place in bis Dictionary or amongst the magic 902.

Listen to his dictum on Ireland:- 'The Irish have been seriously hampered by geographical, and to some extent by linguistic, barriers, as well as by unfortunate political circumstances, in contributing their due share to British civilisation.' How do you define British civilisation? I think it is what has made life dull, ugly, commercial, utilitarian ; it is what has robbed us of our youth, has elipped the wings of our minds. Perhaps Ireland of the future will be able to teach British civilisation to learn again what it had forgotten-that beauty is the soul of the world.

Wales and the Welsh border are allowed to have produced many soldiers and divines, to a slight extent, poets and musicians. The native article is, of course, tabooed. Scotland stands at the hear as regards soldiers, a third going to her account, whilst a fourth of the British philosophers, and a fourth of the men of science are credited to her, and nearly all the great travellers, explorers, and adventurers.

Ireland is allowed to have produced more than her share of soldiers, and a very large proportion of British actors and actresses.

Mr. Ellis adds in a kindly spirit:--' The genius of Ireland is a curiously paradoxical subject, and requires a study in itself. Though so many great men have been associated with Ireland, when we analyse them according to race, we find that a remarkably large proportion of them are of English or Scottish descent. Bishop Berkeley, for instance, is often called an Irishman, yet always considered himself an Englishman. The great Irish patriots have usually had English blood in their veins, and have sometimes even been proud of the fact. And yet while this is so Ireland has somehow had the art of imparting some of her subtlest qualities to those happy Englishmen who have had the good fortune to possess some slight strain of her blood, or be born in her land, or even lived there in youth. The contribution of Ireland to our national genius cannot well be stated in numerical values.'

Here again a native greatness, great for Ireland and in Ireland, does not commend itself to Mr. Ellis. He would not include the O'Clerys, Keating, O'Sullivan Beare, Mangan, or Sir S. Ferguson, but to Ireland they are great. The average Irishman would surrender Bishop Berkeley, in spite of his wise observations in the Querist, without a pang, and the great Irish patriots who usually had English blood in their veins more often forgot it than remembered and were proud.

Once more we see the Celt excelling in the lighter, chivalrous side of life-leaders of men, seekers of adventure, imaginative dissemblers on the stage of life. Our article-writer, however, sees but a proof that when conducted on a broad and impartial basis 'a survey of the racial elements of genius effectually puts out of court those who contend that the intellectual 
ability of Great Britain belongs exclusively, or even in some disproportionately high degree, to one racial element only.' Certain words of Matthew Arnold's might be so interpreted, but the Celts themselves do not arrogate any such position. They only seek to prove by every means in their power that they are still a living people with a living language, which has a right to live and shall live, and knowing that if their various peoples gather together and act in unity, they constitute a formidable and intellectual nationality from which great things may yet arise.

Louisa E. FarquHarson.

\section{An Undetected Norse Loan-Word}

It is the Gaelic pràmh, as thus used :-

1. Am bheil ann ach bruaillean pràmh, A's lionn-dubh mnà, a Dheirdire.

Deirdire, ed. A. Carmichael, 1905, p. 68,

and rendered therein :-

It is but the disturbance of sleep,

And woman's melancholy, $O$ Deirdire !

2. 'Nuair labhradh e prìmhail

Bu chràiteach mo chridhe 'm chorp.

Sàr-Obair, ed. J. Mackenzie, p. 382,

where the reference is on the part of a young maid to the depressed mental state of an old man.

3. Gur e a mheudaich dhomh am pràmh

'S a dh' fhàg mo chadal luaineach.

Oranaiche, ed. Sinclair, p. 7 .

4. 'S nuair a ghabh mi'n sin fadachd

Chaidh mi'n leabaidh fo pràmh (sic).

Ibid. p. 255.

5. 'Nuair a thug thu do chùl rium

Shil mo shùilean gu làr,

Cha'n eil stàth dhomh bhi'g innseadh

Gu'm bheil m'inntinn fo phrìmh.

Ibid.

6. Mar shionnach nam fuar-bheann fo phràmh. 'S mo smuaintean gu truagh dhomh.

Ibid. p. 229. 